(C) Economic Literature, Vol. XII (1-7), December 2014

\title{
Loan Disbursement in Animal Husbandry with Reference to Agriculture Development Bank, Bagar, Pokhara
}

\author{
Yadav Sharma Gaudel* \\ Yashoda Gautam **
}

\begin{abstract}
This article analyzes the loan disbursement pattern from Agriculture Development Bank, Bagar, Pokhara in the past 10 (FY 2060/61-FY 2069/70) years to find out the rate of growth of disbursal for loan and changes in interest rate in animal husbandry and its responses from the farmers in and around Pokhara. The data were based on the internal records of the bank during FY 2060/61 to FY 2069/70. Data show that during the study period (2060-2069), the highest total loan disbursement of ADBN, Bagar was 176.35 million in FY2064/65 and the lowest was 109.74 million in FY 2062/63. The highest loan disbursement in animal husbandry was 16.23 million (14.79\%) in FY 2062/63 and the lowest was 2.57 million (21.60\%) in FY 2060/61. The highest growth rate of loan disbursement in animal husbandry was 214.8\% FY 2061/62. Similarly, the rate of interest for the loan in Animal husbandry was the highest in FY 2060/61 with 16\% per annum and it reached its lowest point in FY 2065/66 at 11\% per annum. The highest amount of principal collection was Rs. 189.27 thousand in FY 2062/63 and the lowest was Rs. 24.69 thousand in FY 2060/61. Farmers are facing the problem of bank loan procedure even though animal husbandry is getting attention of the farmers to increase their investment. However, the beginners of animal husbandry feel discouraged by the tough condition in loan procedure, which shows that the bank policies have not become farmers-friendly.
\end{abstract}

Key Words: loan disbursement trends, repayment trends, animal husbandry, interest rate, agriculture development bank.

\section{BACKGROUND}

Ever since the evolution, animals have been a matter of great value in the life of the human beings. The pre-humans lived on hunting the small creatures. Slowly, they shifted towards farming and later taming the animals that eased them to get the food right around their huts. At the beginning of the human civilization, people knew just about the meat-value of the animals. With time, they learnt other values related with the animals like milk and wool. Animal rearing has been practicing for thousands of years since the first domestication of animals. Yet, the professionalization of

\footnotetext{
* Dr Gaudel is Professor and Head at Department of Economics, P. N. Campus, TU, Pokhara. ** Ms Guatam is Masters research student at the Department.
} 


\section{2/ Yadav Sharma Gaudel \& Yashoda Gautam}

animal rearing began from Europe. Bakewell is known to have started developing new breeds of sheep that could be much profitable. Over the following decades, farm animals increased dramatically in size and quality (Brock et al, 1988).

Keeping the domestic animals like buffaloes, cows, sheep, goats, and pigs to expand the business of livestock, dairy products, meat and other purpose is called animal husbandry. In the past people used to keep the cattle only for the purpose of households but in these days it has become a kind of business. Animal husbandry has highly potential for employment generation. Dairy farming, sheep farming, goat farming and pig farming provide excellent opportunity of self employment for unemployed youth of our country. Animal husbandry is one of the common ways in which the poor build their assets and are able to finance their children's education and other important requirements. They use cattle manure in crop system, biogas energy system and land quality improvement. In this regard, Arora presented his view that through the production of milk and other products, cattle directly contributes to GNP of the country. For all-around cattle development, there should be looked into breeding, feeding, disease control, management and marketing (Arora 1976).

In Nepal as almost the farmers are poor, ADBN has been playing a vital role in poverty reduction by providing loan for them. In order to enhance the income, Bancil has suggested to the farmers to improve the quality instead of increasing the quantity of the cattle. He has also argued that according to the existing cost structure there will be no proper improvement in quality of farming, so the policy of mixed farming and favorable pricing policy is needed for the better performance of the cattle and farm (Bancil, 1971).

Shrestha wrote that ADBN was established in the year 1968 in order to meet the growing needs of agricultural sector. It started with an authorized capital of Rs. 150 million. The bank borrows lending money from the government of Nepal, Nepal Rastra Bank and from multilateral agencies and projects. The total borrowing of the bank was just Rs. 1.8 million in the beginning on July 1968. However, on July 1978 it stood at Rs. 220.2 million within a period of 10 years of its establishment. (Shrestha, 1981: 196).

No doubt, banks and financial institutions can play a very important role in the economic progress of the country. For this purpose, suitable financial and banking policy, tax policy, land reform and subsidies are necessary. Keeping these facts into consideration, this study has set the following objectives:

- To explore the loan disbursement process used in animal husbandry.

- To reveal the interest rate of loan in animal husbandry and other sectors.

- To analyze the trend of loan disbursement during FY 2060/61- FY 2069/70 in animal husbandry.

- To assess the trend of loan and interest repayment status.

\section{DATA AND METHODS}

ADBN has been providing loan in animal husbandry since B.S. 2040. Regional office in western region was emerged for the purpose of looking 6 districts of Gandaki and 4 districts of Dhaulagiri zones. Sub-branch office of Naudada, and the rural sub-branch of Jalpa Road, Pokhara were merged and made a new office as Branch Office, Bagar. Programs of Bhalam, Nirmalpokhari, 
Lwanghalel, Ghachok, Naudada, and Salyan VDCs of Kaski district were adjusted in Bagar Branch Office, Pokhara. Before B.S. 2066 Bagar branch used to invest in 30 VDCs of western part of Kaski districts including Ghandruk, Parche, Ghachok, Lahachok etc. but now it has invested more in Pokhara city including the mentioned places above.

The research applies of both qualitative and quantitative methods. The data were collected by the self-observation. In this research, data and the information were gathered from the staff of the ADBN, Pokhara and the related persons who were keeping the cattle farming as their economic sources. For the primary data, Pokhara and around the valley had been selected. In the study area, most of the farmers are found dependent upon this occupation for their economic earnings. Most of them are found keeping cows and buffalos because it is profitable than other farm animals. Some farmers keep the laborers to run their businesses smoothly according to their firm sizes. Some do not keep the laborers if their family size is large and all the family members are engaged in this business.

\section{RESULTS AND DISCUSSIONS}

Nepalese farmers are poor and they do not have enough property to invest more on animal husbandry. So they have taken loan from the banks, financial institutions and from money lenders too. Some of them are using their own land for cattle farming. Some are paying more than $10 \%$ interest rate to the bank, which is very high. It is very hard to pay back the principal and interest rate as well in time. They must expense most of their incomes to their cattle in purchasing fodder, water, medical treatment, and others. But some are found counting their money income on monthly basis, which keep them in profit to some extent.

Table 1: Interest Rate of ADBN in Different Sectors

\begin{tabular}{clc}
\hline S.N. & \multicolumn{1}{c}{ Sectors } & Interest Rate (\%) \\
\hline 1. & Agriculture loan & 12.0 \\
2. & Agricultural industry & 12.5 \\
3. & Housing & 12.5 \\
4. & Energy (Hydropower, Biogas, Solar) & 12.0 \\
5. & Transportation/ Communication & 12.5 \\
6. & Metal Production & 12.5 \\
7. & Wholesale and Retail Trade & 15.0 \\
8. & Small Farmer & 10.5 \\
9. & Hotel, Motel, Tourism & 13.0 \\
10. & Gold, Silver & 14.0 \\
11. & Services(Hospital, College etc) & 12.5 \\
12. & Overdraft Loan & 15.0 \\
\hline
\end{tabular}

Source: $A D B N, 2070$.

ADBN disburses the loan mainly for agriculture production activities and the agro based enterprises. The bank generally makes loans against collateral security up to limit of $60 \%$ to $80 \%$ of the collateral (Official Report, 2014). The farmers who are willing to borrow the loan from the bank should fill up the prescribed application form of loan provided by the bank. The form should be accompanied by the supporting documents like loan ownership, receipt of land, revenue 


\section{4/ Yadav Sharma Gaudel \& Yashoda Gautam}

payment and receipt of rent payment of a tenant. The records of the bank revels that interest rate was different in different sectors. The lowest interest rate was charged $10.5 \%$ in small farmer sector and the highest was $15 \%$ in overdraft loan. Interest rate structure of ADBN in different sectors is presented in Table 1.

The table 1 shows that the highest interest rate charge was $15 \%$ in wholesale and retail production and in overdraft loan, while the lowest interest rate was $10.5 \%$ in small farmer sector. The bank charged $12.5 \%$ interest rate in most of the other sectors. However, in B.S. 2070, the interest rate in agriculture loan was only $12 \%$.

Table 2: State of Interest Rate in Animal Husbandry during Last Decade

\begin{tabular}{cc}
\hline Fiscal Year & Interest rate in animal husbandry $(\%)$ \\
\hline $2060 / 61$ & 16.0 \\
$2061 / 62$ & 12.5 \\
$2062 / 63$ & 12.5 \\
$2063 / 64$ & 12.5 \\
$2064 / 65$ & 12.0 \\
$2065 / 66$ & 11.0 \\
$2066 / 67$ & 12.0 \\
$2067 / 68$ & 13.0 \\
$2068 / 69$ & 12.5 \\
$2069 / 70$ & 12.5 \\
\hline
\end{tabular}

Source: $A D B N, 2070$

The table shows the rate of interest in loan for animal husbandry on annual basis within the study period from FY 2060/61 to FY 2069/70. The bank had charged the highest rate of interest (i.e. $16 \%$ ) in FY $2060 / 61$ and that dropped to $12.5 \%$ in the next year. From the table 1.2 it is also clear that the lowest rate was taken in FY 2065/66 which was $11 \%$ only.

The table 3 shows that the highest total loan disbursement was Rs. 176.35 million in the FY 2064/65 and the lowest was Rs. 109.74 million in FY 2062/63. But at the same year (2062/63), the highest amount (Rs.16.23 million) was provided in animal husbandry. The lowest amount of loan in animal husbandry was Rs. 2.57 million in the FY 2060/61 only. As the growth rate shows, loan disbursement in animal husbandry was highly increased in FY 2061/62 by $214.8 \%$ and sharply declined in FY 2065/66 by 40.3\%. 
Table 3: Total Loan Disbursement of ADBN, Bagar (2060- 2069)

(Rs. in millions)

\begin{tabular}{cccc}
\hline $\begin{array}{c}\text { Fiscal } \\
\text { year }\end{array}$ & $\begin{array}{c}\text { Total loan } \\
\text { disbursement }\end{array}$ & $\begin{array}{c}\text { Loan in animal } \\
\text { husbandry }\end{array}$ & $\begin{array}{c}\text { Growth rate in animal } \\
\text { husbandry (in \%) }\end{array}$ \\
\hline $2060 / 61$ & 119.01 & 2.57 & - \\
$2061 / 62$ & 143.54 & 8.09 & 214.8 \\
$2062 / 63$ & 109.74 & 16.23 & 100.5 \\
$2063 / 64$ & 139.37 & 15.62 & -3.8 \\
$2064 / 65$ & 176.35 & 12.96 & -17.0 \\
$2065 / 66$ & 123.80 & 7.74 & -40.3 \\
$2066 / 67$ & 128.17 & 9.82 & 26.9 \\
$2067 / 68$ & 119.15 & 15.71 & 59.9 \\
$2068 / 69$ & 153.31 & 14.16 & -9.9 \\
$2069 / 70$ & 160.70 & 15.90 & 12.3 \\
\hline
\end{tabular}

Source: ADBN, 2070.

The information shows that the rate of interest and the loan disbursal were somehow related to each other. In many cases apart from the social changes, the bank seemed to have been conscious about the demand of the farmers in the case of interest rate. However, as a commercial bank whenever ADBN had received a large number of customers or demand for loan, the bank had increased its value in loan disbursement by decreasing interest rate.

With regard to loan disbursement among the different animal husbandries, the research also presents an unequal tendency of demand in cows/buffaloes, pigs and goats farming. In a nutshell, the increase in the disbursal of loan is clearly seen in each fiscal year within a specified 10 years time period. The cows/buffaloes and pigs made almost six-fold increment, whereas that in goats farming is more than ten-times. This will be clear from the Table 4.

Table 4: The Comparison of Loan Disbursement among the Cows/Buffaloes, Pigs and Goats Farming (FY2060/61- FY2069/70) (Rs. in '000)

\begin{tabular}{lllll}
\hline Fiscal Year & \multicolumn{1}{c}{ Loan in Cow/Buffalo } & \multicolumn{1}{c}{ Loan in Pig } & \multicolumn{1}{c}{ Loan in Goat } & Total \\
\hline $2060 / 61$ & $2396(93.19 \%)$ & $50(1.94 \%)$ & $125(4.86 \%)$ & 2571 \\
$2061 / 62$ & $6735(83.20 \%)$ & $91(1.12 \%)$ & $1269(16.00 \%)$ & 8095 \\
$2062 / 63$ & $15865(97.72 \%)$ & $80(0.49 \%)$ & $289(1.78 \%)$ & 16234 \\
$2063 / 64$ & $15277(97.80 \%)$ & $25(0.16 \%)$ & $320(2.05 \%)$ & 15622 \\
$2064 / 65$ & $12721(98.15 \%)$ & $120(0.93 \%)$ & $995(7.68 \%)$ & 12961 \\
$2065 / 66$ & $7154(92.44 \%)$ & $440(5.69 \%)$ & $145(1.87 \%)$ & 7739 \\
$2066 / 67$ & $8868(90.32 \%)$ & N/D & $950(9.68 \%)$ & 9818 \\
$2067 / 68$ & $14996(95.48 \%)$ & $710(4.52 \%)$ & N/D & 15706 \\
$2068 / 69$ & $12776(90.25 \%)$ & $150(1.06 \%)$ & $1230(8.69 \%)$ & 14156 \\
$2069 / 70$ & $14156(89.00 \%)$ & $300(1.89 \%)$ & $1448(9.10 \%)$ & 15904 \\
\hline
\end{tabular}

Source: $A D B N, 2070$

Note: N/D- Not Disbursed 


\section{6/ Yadav Sharma Gaudel \& Yashoda Gautam}

Table 4 depicts that the loan for cows/buffalo stands at the biggest amount which is quite incompatible to the other two i.e. pigs and goats. In the first year of the decade, the loan for cows/buffaloes was around twelve-fold the sum of that for pigs and goats. In FY 2060/61, the loan was about Rs. 2396 thousand but the other two took about Rs. 50 thousand and Rs. 125 thousand respectively. But in FY 2061/62 the disbursal increased by about ten-fold in goats but just around double in pigs and about three-fold in cows/buffaloes. Surprisingly, it was changed in the second year of the decade. The loan fell slightly in pigs but sharply in goats as Rs. 25 thousand and Rs. 320 thousand accordingly, whereas it climbed up more than double in cows/buffaloes in FY 2063/64 and reached Rs. 15277 thousand. The statistics shows that the loan disbursal has always been the highest for cows/buffaloes, but the lowest for pigs except in FY 2065/66 when the loan disbursal in pigs was around three times more than that in goats. The table shows that though the loan disbursal fell back both in cows/buffaloes and goats in FY 2065/66, it was increased in pig and met 440 thousand. The same kind of inconsistency is seen even in FY 2064/65 when the loan was increased by almost three-times in pig and goats; it dropped down in cows/buffaloes. In FY 2062/63 it was quite opposite when the loan disbursal dropped in pigs and goats, it went up in cows/buffaloes.

Table 5 demonstrates that the repayment status of the loan and the interest is not stable in ADBN, Bagar, Pokhara. In FY 2060/61 the bank showed its more flow to farmers than in collecting back. While checking the repayment status of FY 2066/67, it can be said that the bank has made a big collection from many of the farmers whose repayments were at due. In that year the bank collected Rs.71.68 lakh more than the disbursement under the repayment. Except for the first, fourth, sixth and the ninth, the bank has been able to get more repayment than the disbursement amount. The interest collection was the highest in the last fiscal year 2069/70 and the lowest in the first FY 2060/61 of the study period.

Table 5: Repayment Status of Loan and Interest in Animal Husbandry (2060-2069)

\begin{tabular}{ccrc}
\hline Year & Loan Disbursement & Principal Collection & Interest Collection \\
\hline $2060 / 61$ & 25.71 & $24.69(96.03 \%)$ & 5.48 \\
$2061 / 62$ & 80.95 & $96.18(118.81 \%)$ & 15.51 \\
$2062 / 63$ & 162.34 & $189.27(116.59 \%)$ & 27.27 \\
$2063 / 64$ & 156.22 & $141.38(90.50 \%)$ & 26.67 \\
$2064 / 65$ & 129.61 & $130.94(101.03 \%)$ & 24.39 \\
$2065 / 66$ & 77.39 & $69.02(89.18 \%)$ & 27.93 \\
$2066 / 67$ & 98.29 & $169.97(172.93 \%)$ & 36.30 \\
$2067 / 68$ & 156.70 & $176.28(112.93 \%)$ & 34.18 \\
$2068 / 69$ & 141.06 & $132.68(94.06 \%)$ & 37.56 \\
$2069 / 70$ & 159.04 & $161.92(101.81 \%)$ & 39.92 \\
\hline
\end{tabular}

Source: $A D B N, 2070$.

In compare to other fiscal years, the loan disbursement was the highest in FY 2062/63 with Rs. 162.34 lakh, but the interest collection was much lower in this year than in other fiscal years. Similarly, though the bank disbursed almost the same amount of money i.e. Rs. 156.22 lakh in FY 
2063/64 and Rs.156.70 lakh in FY 2067/68, there was a huge gap in interest collection. The record shows that once the interest rate was brought down to the lowest point the farmers came up to pay at least the interest. So from that year it can be noticed the collection of the interest is going up every year. During the FY 2066/67 only Rs. 77.39 lakh was disbursed but the interest collection was Rs.27.93 lakh, which was much higher as compared to the past years. This encouraged the interest collection even the following year with an increment of Rs. 8.37 lakh. From this analysis it is clear that though the disbursement was not so high, the interest collection kept growing when the bank lowered the interest rate.

\section{CONCLUSION}

From the foregoing analysis it can be concluded that ADBN, Bagar, Pokhara has been making significant contributions to the farmers through its lending operation, yet the services seemed to have reached only to a handful of people. Since the bank has been promoting different agro-based industries for long, it has the variations in the amount of loan delivered too. Data show that it has disbursed the biggest amount of loan for cows/buffaloes and the least has gone to pigs farming. Besides being costly in its original price, cows/buffaloes rearing need much space, fodder and other veterinary expenditures too. The demand for loan under this category seems to be big because of numerous reasons. The farmers can earn from anyway around like dung or urine or milk or the sale of buffaloes for meat after when it turns sterile. Surely, the farmers feel some problems in this occupation. The goat-keepers feel the risk of the wild animals in times of grazing. The pigs cause much bad smell in the locality and the neighbors hardly want it be started closely so sometimes the renters need to pay big for the space. Additionally, it has a limited market.

Despite all these challenges they need to earn to compensate their labor and the bank loans too. Goat-rearing has some strong points behind its high loan disbursement. The research shows that the goats can be sold very easily and quickly within the local market. Similarly, the little fodder they demand can be managed from the forestry around the valley. Though animal husbandry is getting attention, the farmers are struggling with the common problem of the care-takers, unpredictable life of livestock and the troublesome bank loan procedure. They feel that if the cattle die they have nothing to compensate with for the loan obtained from the bank. Many farmers complained on the complex structures in the bank loan so they prefer going to some other private sectors rather than applying for the loan in ADBN. The condition of the bank-loan to show up the alternative source of income so as to guarantee the regular payment of the interest is a difficult part of obtaining the loan. The beginners feel discouraged by this tough condition in loan procedure. It shows that the bank policies have not been the farmers-friendly.

\section{REFERENCES}

Arora, R.C. (1976). Development of Agriculture and Allied Sector. New Delhi: S.Chand and Co. Pvt. Ltd, Rajendra Ravindra Printers.

Bancil, P.C. (1971). Agricultural Planning for 700 Millions :A Perspective Study. Bombay: Lalvani Publishing House, Sujit J. Patwardhan at Sangam Press

Brock, Clutton, Hall S and Juliet, (1988). Two Hundred Years of British Farm Livestock. London: Natural History Museum Publications.

Shrestha, D. P. (1981). An Introduction to Nepalese Economy. Kathmandu: Ratna Pustak Bhandar. 